\title{
An Insurmountable Past? Xenophobia in Germany Today
}

\author{
Ronald Webster
}

To a certain degree I am qualified to comment on the emergence of a deep hostility to foreigners in today's Germany. Until 1983 I spent almost twenty years of my life in former West Germany, and although apparently shielded from such experiences by being married to a German, even I experienced milder forms of xenophobia (Auslãnderfeindlichkeit) towards the end of my stay there.

Fundamentally, as all social scientists know, xenophobia is caused by a deeply ingrained group and individual instinct of mistrust and hostility towards those who are "foreigners." These tribal instincts, some would argue, are passed on from generation to generation. Inherited or otherwise, there is no doubt that the herd instinct manifests itself in hostility towards visibly different "intruders," as exemplified in Germany today.

At the same time, it must be said that these current hostilities are not peculiar to the Germans, but due to their past dealings with foreigners and those they have defined as "foreign." The Germans have understandably aroused more international attention and censure than other nations. Moreover, as a further extenuating circumstance, it should be pointed out that more foreigners either reside or seek asylum in Germany today than in any other Western European country. According to the highly respected German weekly, Die Zeit, there are no less than 5.7 million foreigners living in Germany today. ${ }^{1}$ Germany's renowned news magazine, Der Spiegel, in its inimical polemical style, puts matters more bluntly by pointing out that Germany's population now exceeds "the current population of the former

Ronald Webster teaches in the Department of History at York University. colonial states of France and Great Britain," 2 with the highest percentage of foreigners in Europe and, with 46 percent of the European total, Germany has received the most persons seeking political asylum among all industrialized countries.

Consistent with its more dramatic view of the situation, Der Spiegel emphasizes what it perceives to be the all-too liberal aspects of German asylum laws, in which it quotes German experts who call the laws "extremely generous," making them a "magnet" for persons applying for asylum. In raw statistics, Der Spiegel states that 193,000 aspiring refugees came to Germany in 1990, with less densely populated France a distant second, taking 56,000. The news magazine also projects that these figures will rise. ${ }^{3}$

Indeed, the current turmoil in Germany centres mainly around visible violence by skinheads and neo-Nazis has been in the East.

More rational Germans argue that these events are not surprising, given the years of pent-up frustration East Germans endured under the Communists and, of course, given present unemployment levels ranging over 20 percent of the Eastern workforce. Moreover, and most relevant here, under the Communist regime East Germans were not permitted to demonstrate publicly against the presence of Africans and Asians studying in significant numbers at their universities, while many young East Germans could not study at all due to active religious involvement or other alleged offences they had perpetrated against the dominant Communist ideology. Such perceived governmental favouritism, formerly opposed more or less in silence by suppressed "natives," is now allowed

\section{Fundamentally, as all social scientists know, xenophobia is caused by a deeply ingrained group and individual instinct of mistrust and hostility towards those who are "foreigners."}

minorities seeking asylum, rather than all non-Germans living in their midst, although, as stated at the outset, the "nonvisible" minorities have also felt the effects of this recent hostility.

To turn to the central issues at hand, the native Germans' dislike of foreigners is accentuated these days, especially in former East Germany, with its peculiar combination of adjustment trauma and a decided tendency to seek non-German scapegoats for the economic woes these "new" Germans are now enduring. Although recent antiforeign eruptions have taken place in almost all corners of the enlarged Federal Republic, the main focus of demonstrations and acts of to vent itself more openly, for better or worse.

Several other fundamental aspects of the problem for all of Germany also need to be addressed. Firstly, as a result of extended phases of political isolation in their history and then of Nazi extermination policies, the Germans really had very little everyday contact with foreigners. Thus, to be labelled an Auslānder in German-speaking areas, beyond the word's hostile connotations, was and to some degree still is tinged even with exotic qualities. For example, I recall an American acquaintance from my student days in Germany recounting a trip he took with an international group 
of students into the backwaters of Austria in the early 1970s. In the group was a Chinese student. The villagers showed a great deal of curiosity towards these exotic Asians, a curiosity that

\section{As a historian I would be inclined to argue that Germans have been for a long time very ethnically unsure of themselves, an uncertainty that has heightened their suspicions of foreigners.}

bordered in this case on the impolite. Indeed at the time my fellow student learned that the people of these particular hinterland villages had never seen an Asian before. And, it must be added, the backwaters in Germany and Austria are much the same today.

Secondly, the Germans themselves have been constantly subjected to cultural, linguistic and ethnic pressures from their more powerful and often ethnically more consolidated neighbours. As a group of Die Zeit journalists wrote recently, ${ }^{4}$ perhaps no European people has been more exposed to ethnic intermingling than the Germans. From the East and Southeast came the Slavs, the Huns and the Tartars, from the West the Celts, from the North the Vikings, and from the South the Romans and other Mediterranean peoples. The city of Colognetracesits origins to Romantimes and one of Cologne's most cherished Christian customs, the pre-Lenten carnival rites, go back to aspects of the Egyptian Isis cult. ${ }^{5}$ Germany's venerable thinker and poet, Johann Wolfgang von Goethe, had a Turkish ancestor. Frederick the Great spoke French, and he claimed he only used German with his coachman. Right into the Bismarck period after 1870, Germans were wont to accuse their fellows of aping foreigners, of an excessive desire to emulate their ways. No wonder Hitler's fantastic brand of Aryan ideology, unscientific as it was, gained such popular credence.
Thirdly, the Cold War has had a particular impact on the Germans' sense of nationality, which inevitably influenced recent events. In the East before 1989 the Communists downplayed the nation and nationalism, since Communist ideology and propaganda laid claimed to an overriding sense of the brotherhood of the toiling classes. It was therefore common practice before 1989 for the East German regime to try culturally and politically - even linguistically - to erect a symbolic national wall to match the physical one dividing East and West Germans. This left a scar in both parts of Germany, which was manifested by a continuing identity crisis in the East in the form of uncertainties about themselves as Germans and desperate if often clandestine attempts to identify with their vastly richer and apparently more ethnically and socially integrated Western counterparts.

In West Germany Communism heightened insecurities about national identity too. After 1945, in order to demonstrate to the rest of the world that Germany was still a cohesive nation, one especially deserving of Western sympathy, political respect and military protection, West Germans struggled to knit together the bonds of Germanness that were then being severed by the regime in the East in the name of a higher Communist nationality. Until the concrete barrier to immigration was erected in 1961, there was also the question of integrating some eleven million ethnic Germans from such distant areas as the Volga, Siberia, Yugoslavia, Hungary, Czechoslovakia and Poland. Moreover, the Russian and Polish-German refugees often carried with them the additional burden of having only the vaguest contacts with the German language and culture due to understandable anti-German feelings in these lands, especially after $1933 .^{6}$

As a historian I would be inclined to argue that Germans have been for a long time very ethnically unsure of themselves, an uncertainty that has heightened their suspicions of foreigners. Their relatively recent and first stab at unification in 1870, their determination to purge thelanguage and culture of foreign influences thereafter, right down to the grotesque and pernicious antiforeign propaganda and experiments of the Nazi era and their postwar problems, are all symptoms of a deeply rooted sense of ethnic insecurity. Centuries of foreign intervention, already alluded to here, merely reinforce this tendency.

Nevertheless, after 1945, after the termination of all Hitlerian experimentation, despite a still extant xenophobia, in a series of major agreements the West Germans allowed Portuguese, Spaniards, Turks, Yugoslavs, Greeks and North Africans into the workforce. There are 1.6 million Turks in Germany today? These so-called "guest workers" (Gastarbeiter) have always been regarded as only temporary residents and, for the most part, did not and do not enjoy German civil rights. Indeed even vaunted strict German school attendance laws have been occasionally waived for such foreigners. I know of one instance in Southwest Germany, in

\section{But much of what has \\ been said here could be said of Canadians and Americans, who live in far more multicultural settings than do the insular Germans, and this point must be kept in mind.}

which school-aged children of Greek and Turkish workers were not obliged to attend German schools at all. Among them was a sixteen-year-old illiterate Greekgirl who resided with her family in Germany throughout the 1970s. To my knowledge the parents of these children were never officially instructed to observe German educational laws. ${ }^{8}$ It need hardly be added that waiving such rules had nothing to do with a concession to the foreign worker and his family, but served the less laudable goal of excluding them from using public facilities and, perhaps, to uphold an unwritten code of 
segregation.Thus today for a variety of reasons Germany has a large foreign, nonintegrated population that is really viewed as temporary help. Compounding the foreign workers' problems has been the flood of persons seeking asylum from Asia, the Near East and Africa: Vietnamese boat people, Tamils, Iranians, Afghans, refugees from dictatorial African regimes, all of whom have sought refuge in Germany because the West German political asylum laws are still among the most generous in the world; also because of the rightly vaunted German social network and extremely high standard of living.

However, for the overwhelming majority of those seeking refuge in Germany today, there can be no question of their even being classified as "guest workers," of enjoying the perks of Germany's social and health insurance systems beyond the shortest possible term. Thus these young men and women are assigned inadequate emergency housing and condemned to an idle existence. While their backlog of claims for asylum are being considered, these refugees cannot work, and are therefore at the mercy of the public, while allegedly hard-working and unemployed Germans view the refugees' apparent idleness with deep suspicion. The fact that these foreigners happen to be black orbrown merely intensifies the hostilities and prejudices shared by the indigenous population.

But much of what has been said here could be said of Canadians and Americans, who live in far more multicultural settings than do the insular Germans, and this point must be kept in mind. What makes the German case so blatant is the burden of the Nazi past, also because the current Conservativeled coalition government is fanning the flames of xenophobia to a certain degree. With the greatest political difficulty, while being very much in the public eye, Chancellor Kohl's Christian DemocratFree Democrat coalition government is currently attempting to draft a bill in the German parliament that would severely limit the right to seek political asylum in Germany. Because of the difficulties the political parties are having in finding a

common denominator on this subject, even President Richard von Weizãcker has been forced to take the unprecedented step, and without prior parliamentary sanction, of intervening in the debate to admonish the parties to get their acts together and to come up with a comprehensive and fair bill on asylum. ${ }^{9}$

Indeed the whole Auslãnder debate is now being exacerbated by a further issue - what high-placed German

\section{...Chancellor Kohl's Christian Democrat-Free Democrat coalition government is currently attempting to draft a bill in the German parliament that would severely limit the right to seek political asylum in Germany.}

officials are now negatively labelling as the policy of "inserting" incompatible foreign elements. What they mean is that foreigners are allowed personal and collective equality in the host country, but are in fact merely "inserted" unassimilated into the society, creating a multicultural and heterogeneous mosaic. Such Germans fear that this policy will result in a multiplicity of cultures and, interestingly enough, they expressly use the negative Canadian experience to illustrate why such a policy is in their words "illusory." 10

Both the critics and supporters of the acrimonious debates swirling around the proposed asylum bill understand that these disputes provide gratuitous encouragement to the radical bands involved in the torchings and vandalism in and around shelters for those seeking asylum. If, for example, the politicians believe that the refugees are getting into the country too easily, how can one blame the unemployed skinhead from smashing a few windows, or beating up a few blacks who may venture into some "pure" German pub or discotheque?

Alas, there appears to be a general consensus that Hoyerswerda, the Saxon town that for five days last fall was the centre of officially unhindered violence against foreign refugees, is a symptom that there is a real problem that must be addressed. This was especially true when the news of this five-day spree of animosity to refugees spread to all parts of Germany, making the slogan "Hoyerswerda is everywhere" a selffulfilling prophecy. Moreover, it demonstrated that public and private attitudes reflected a regrettable sense of Auslãnderfeindlichkeit. Thus, the xenophobic perception of the culture under siege from an uncontrollable foreign horde seems indeed to be weighing heavily on the Germans these days, just when their most cherished dream of reunification has now become a reality, just when the cement of togetherness seems to be in the process of repairing the bonds rent in the past by the phobias cultivated by two world wars and the burden of Germany's deeper past. [.

\section{Notes:}

1. "Das Deutsche und das Fremde," Die Zeit, International Edition, 45, November 8, 1991: 7.

2. "Lieber sterben als nach Sachsen," Der Spiegel, September 30, 1991: 32-33.

3. Der Spiegel, September 30, 1991: 33.

4. "Das Deutsche und das Fremde," Die Zeit, November 8, 1991.

5. Die Zeit, November 8, 1991: 7.

6. For an example of problems faced by ethnic Germans from Russia, see "Die unvergessene Republik," Die Zeit, October 25, 1991: 5-6.

7. "Ali im Wonderland," Die Zeit, November 8, 1991: 13.

8. I have to admit that it was my own German father-in-law who rented such primitive accommodations to some of these people, from whom I thus learned of their widespread illiteracy:

9. Die Zeit of November 29, 1991, has an indepth analysis of Weizãcker's unprecedented and constitutionally questionable step: Robert Leicht, "Es ist etwas faul im Staate Deutschland."

10. Dr. Eckart Schiffer, Chefdenker in the current German Ministry of the Interior [Innenministerium]; "Der Koran ist nicht Gesetz," Der Spiegel, September 30, 1991: 59. 